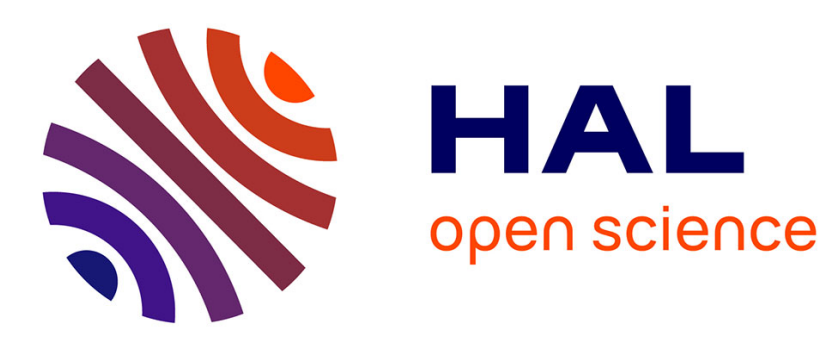

\title{
Feeding on frozen live yeast has some deleterious effects in Drosophila melanogaster
}

Eric Le Bourg, Tiphaine Gauthier, Hervé Colinet

\section{To cite this version:}

Eric Le Bourg, Tiphaine Gauthier, Hervé Colinet. Feeding on frozen live yeast has some deleterious effects in Drosophila melanogaster. Experimental Gerontology, 2015, 69, pp.202-210. 10.1016/j.exger.2015.06.019 . hal-01174218

HAL Id: hal-01174218 https://hal-univ-rennes1.archives-ouvertes.fr/hal-01174218

Submitted on 8 Jul 2015

HAL is a multi-disciplinary open access archive for the deposit and dissemination of scientific research documents, whether they are published or not. The documents may come from teaching and research institutions in France or abroad, or from public or private research centers.
L'archive ouverte pluridisciplinaire HAL, est destinée au dépôt et à la diffusion de documents scientifiques de niveau recherche, publiés ou non, émanant des établissements d'enseignement et de recherche français ou étrangers, des laboratoires publics ou privés. 
Feeding on frozen live yeast has some deleterious effects in Drosophila melanogaster

\section{Eric Le Bourg ${ }^{*}$, Tiphaine Gauthier ${ }^{2}$, Hervé Colinet ${ }^{3}$}

1: Université Paul-Sabatier, Centre de Recherches sur la Cognition Animale, UMR CNRS 5169, 31062 Toulouse cedex 9, France

2: Université Paul-Sabatier, UMR CNRS 5088 LBCMCP, 31062 Toulouse cedex 9, France

3: Université de Rennes, UMR CNRS 6553 ECOBIO, 263 avenue du Général-Leclerc, CS 74205, 35042 Rennes, France

*: to whom correspondence should be sent:

eric.le-bourg@univ-tlse3.fr 


\begin{abstract}
Many experiments have shown that dietary restriction, for instance by removing live yeast or modifying the protein/carbohydrate ratio, can modulate lifespan, fecundity, resistance to severe stresses and behaviour in Drosophila melanogaster flies. The present study tested whether feeding flies with frozen yeast rather than with fresh yeast could have some effect on these traits, the other components of the food being similar in the two groups. Freezing altered live yeast quality and flies feeding on frozen yeast lived slightly less (males), were less fecund at older ages, and poorly resisted to some severe stresses (cold and starvation), no negative effect being observed on resistance to heat. It seems that, like in humans, feeding on a low quality food can negatively impact healthspan and that an appropriate food is not only a food with optimal number of calories and appropriate ratios of proteins, carbohydrates, and fat.
\end{abstract}

\title{
Key-words
}

Nutrition - live yeast - freezing - lifespan - fecundity - stress - metabolomics Drosophila melanogaster 


\section{Introduction}

It has been accepted for many years that " 'restricting nutrients without malnutrition extends lifespan and reduces age-dependent decline and diseases in virtually all species', (Greer and Brunet 2009) and that this effect "is the result of a decrease in energy intake and not the result of a change in one specific nutrient” (Ramsey et al., 2000). Both these views were challenged when it was shown that lifespan was not increased in some species (review in Le Bourg, 2010), particularly in some mice strains (Liao et al. 2010), and in monkeys (compare Mattison et al., 2012 and Colman et al., 2014, and see a comment in Hulström, 2015), and that calories could be not at play. Indeed, it is now accepted that, the caloric content being constant, the proteins/carbohydrates ratio modulates lifespan, for instance in Drosophila melanogaster flies (e.g. Vigne and Frelin, 2007ab, Lee et al., 2008, Bruce et al., 2013, Zajitschek et al., 2013) and in mice (Solon-Biet et al., 2014). Therefore, the mainstream hypothesis to explain the positive effect of dietary restriction (DR) on lifespan, when observed, is now more subtle than it was, because it deals with the ratio of nutrients rather than simply with the number of calories.

DR studies in D. melanogaster have provided contradictory results, some authors reporting positive effects of DR on lifespan and others showing no effect (reviews in Le Bourg and Minois, 2005; Le Bourg, 2010). Particularly, some authors have modified the protein:carbohydrate (P:C) ratio by restricting live yeast, a source of proteins (Chippindale et al., 1993, Le Bourg and Minois, 1996, Le Bourg and Le Rohellec, 2009), or by varying the quantity of amino acids (e.g. Zajitschek et al., 2013) or of dead yeast (e.g. Vigne and Frelin, 2007ab, Zajitschek et al., 2013). However, while restricting live yeast could increase longevity and delay locomotor ageing, it also decreased resistance to strong stresses such as cold, starvation, and infection (Le Bourg and Le Rohellec, 2009; Colinet and Renault, 2014), which shows that removing live yeast has contrasting effects in flies.

Beyond the P:C ratio, it could be possible to add a new dimension in studies of DR by modulating the quality of the food, rather than its quantity. Therefore, the present article describes an attempt to modulate lifespan and resistance to severe stresses by using a postulated low-quality food: previously frozen live yeast. As far as we know, no such experiment has been done and frozen live yeast could have deleterious effects, because freezing is detrimental to live yeast and could alter its nutritional quality (e.g. Nakamura et al., 2009). 
The present article reports the effect of freezing live yeast on longevity, fecundity, resistance to severe stresses, climbing activity at various ages and describes the metabolic features of frozen yeast. Material and methods were different in the two labs performing the experiments on flies (called TLS and RNS in the following, according to the International Air Transport Association codes of the cities of the authors, Toulouse and Rennes in France) and are described below.

\section{Material and methods}

\section{Live yeast}

A single Saccharomyces cerevisiae strain is used in all yeast Hirondelle Bleue ${ }^{\mathrm{TM}}$ packs, as confirmed by the manufacturer (Lesaffre International ${ }^{\mathrm{TM}}$ ), and Hirondelle Bleue ${ }^{\mathrm{TM}}$ was used in all the experiments. To obtain frozen yeast, both labs added live yeast at the surface of the medium of large petri dishes containing the respective rearing media of the two labs (see below) and the dishes were stored at $4^{\circ} \mathrm{C}$ for one day (RNS) or 4 days (TLS) before being frozen at $-20^{\circ} \mathrm{C}$ (RNS) or $-12^{\circ} \mathrm{C}(\mathrm{TLS})$.

\section{Flies}

Experiments were performed in TLS and RNS with different rearing procedures and strains.

The TLS lab used the Meyzieu wild strain caught at the end of the 1970s near the city of Lyon, France. The strain was maintained by mass-mating in bottles. Flies were fed on a medium made of agar (20 g/L of distilled water), sucrose (128.57 g/L), corn meal (100 g/L), deactivated brewer yeast (Sigma Y4625: $15 \mathrm{~g} / \mathrm{L}$ ), a mould inhibitor (para-hydroxymethyl-benzoic acid) and enriched with live yeast at the surface of the medium. In order to obtain the parents of the experimental flies, flies laid eggs for one night in a bottle. About 50 pairs emerging from this bottle 9-10 days after egg-laying were transferred to bottles (ca 25 pairs in a bottle): these flies are the parents of the experimental flies. Experimental flies were obtained as follows: eggs laid by ca 5 day-old parents during a ca $15 \mathrm{~h}$ period on a Petri dish containing the medium coloured with charcoal and a drop of live yeast were transferred by batches of 25 into $80 \mathrm{~mL}$ glass vials. In all experiments (except for the fecundity experiment, see below), virgin flies with a duration of preimaginal development of 9-10 days were transferred at emergence under ether anaesthesia in groups of 15 flies of the same sex to $20 \mathrm{~mL}$ polystyrene vials containing the rearing medium. 
Flies lived on vials with fresh or frozen live yeast deposited at the surface of the medium ca one hour before using the vials, yeast being frozen several weeks or months before experiment (freezing method described above). Flies spent their life in an incubator $\left(25 \pm 0.5^{\circ} \mathrm{C}\right.$; 12L:12D) and were transferred to new vials twice a week, vials being kept at ambient temperature for ca one hour before being used. In the following, the date of emergence is indicated by the number of the week in the calendar year (e.g. the first week of 2014 is 1/2014).

The RNS lab conducted experiments on a mass-bred D. melanogaster line derived from a wild population initiated in October 2011 at Plancoët (Brittany, France). Prior to the experiment, flies were maintained in $200 \mathrm{~mL}$ bottles at $25 \pm 1^{\circ} \mathrm{C}$ (16L:8D) on a standard fly medium (RNS medium) consisting of deactivated brewer yeast (80 g/L, MP Biochemicals, Illkirch, France), sucrose (50 g/L), agar (15 g/L), kalmus (9 g/L, see Kalmus, 1943) and parahydroxymethyl-benzoic acid. To generate flies for the experiments, groups of 15 mated females were allowed to lay eggs during $6 \mathrm{~h}$ in bottles $(200 \mathrm{~mL})$ containing $25 \mathrm{~mL}$ of standard fly medium. This controlled procedure allowed larvae to develop under uncrowded conditions at $25 \pm 1^{\circ} \mathrm{C}$ (16L:8D).

\section{Starvation resistance}

Three replicate experiments (TLS) involved vials with fresh or frozen live yeast, yeast being frozen ca 90, 120, or 130 days before experiment, depending on the group of flies (respective groups 41/2014, 45/2014, 46/2014: 3, 4, and 4 vials of 15 flies for each sex and medium group). Flies were transferred at 12 days of age into vials containing a medium only made of agar renewed twice a week. Mortality was recorded every $12 \mathrm{~h}$ up to the death of the last fly. Survival data were analysed with an analysis of variance (ANOVA: sex, medium, replicate factors and all interactions).

\section{Resistance to cold}

Two replicate experiments (TLS) involved vials with fresh or frozen live yeast, yeast being frozen ca 120 or 130 days before experiment, depending on the group of flies (groups 45/2014 and 46/2014: 3 or 4 vials of 15 flies for each sex and medium group). Flies were transferred at 12 days of age in empty polystyrene vials (Falcon 2045) stored in ice at $0^{\circ} \mathrm{C}$ for $24 \mathrm{~h}$ and, after that, transferred back to their rearing vials at $25^{\circ} \mathrm{C}$. The percentage of survivors three days (72 h) after the cold shock was recorded. This percentage was analysed with a logistic model 
testing for the effect of sex, medium, replicate and all interactions.

Two other experiments (RNS) involved vials with fresh or frozen live yeast deposited at the surface of the medium $24 \mathrm{~h}$ before using the vials, yeast being frozen 60 days before the experiment (group 46/2014: 5 vials of 10 flies for each sex, cold stress and medium group). In a first experiment, vials of flies were transferred at 5 days of age in a cold incubator (Model MIR154; Sanyo Electric Co. Ltd.) set at $0^{\circ} \mathrm{C}$ in darkness for $24 \mathrm{~h}$ and, after that, transferred back to their rearing vials at $25^{\circ} \mathrm{C}$. In a second experiment, groups of 10 flies were placed in $42 \mathrm{~mL}$ glass vials and then immersed for 90 or $120 \mathrm{~min}$ in a glycol solution cooled to $-3.5^{\circ} \mathrm{C}$ and, after that, transferred back to their rearing vials at $25^{\circ} \mathrm{C}$. The percentage of survivors three days $(72 \mathrm{~h}$ ) after each of these cold shocks was recorded. This percentage was analysed with logistic models testing for the effect of sex, medium, and their interaction (experiment at $0^{\circ} \mathrm{C}$ ), and the effect of sex, medium, length of cold stress and all interactions (experiment at -3.5 $\circ \mathrm{C})$.

\section{Resistance to heat}

Two replicate experiments (TLS) involved vials with fresh or frozen live yeast, yeast being frozen ca 200 or 230 days before experiment, depending on the group of flies (respective groups 3/2015 and 8/2015: 5 vials of 15 flies for each sex and medium group). Resistance to heat was observed at 13 days of age. Flies were transferred just before the heat shock into empty polystyrene vials (diameter: $17 \mathrm{~mm}$, length: $63 \mathrm{~mm}$ ), the plug containing absorbent cotton with distilled water to prevent desiccation, and kept in a water-bath set at $37^{\circ} \mathrm{C}$ for $90 \mathrm{~min}$. Thereafter, they were transferred back to their vials at $25^{\circ} \mathrm{C}$ and the percentage of survivors one day after the heat shock was recorded. This percentage was analysed with a logistic model testing for the effect of sex, medium, and their interaction.

\section{Fecundity}

Two experiments were done (TLS). In a first experiment, single virgin females (group $36 / 2014)$ were placed at emergence in laying boxes $(40 \times 55 \times 80 \mathrm{~mm})$ derived from the model designed by David and Clavel (1968). A dish (diameter: $40 \mathrm{~mm}$, height: $15 \mathrm{~mm}$ ) containing the rearing medium coloured in black with charcoal was inserted into an opening at the bottom of the box. A drop of fresh (fresh yeast group) or frozen live yeast (frozen yeast group) was put on the medium or not (no yeast group; $n=12$ females in each group). The first day of experiment the 
yeast was frozen for ca 70 days. Dishes were replaced daily and eggs were counted under binocular vision until day 23 (white eggs are easily seen on the black medium). In a second experiment, a pair of flies (group 41/2014) was placed at emergence in laying boxes and the whole procedure was the same as for virgin females ( $n=12$ pairs in each group). The first day of experiment the yeast was frozen for ca 90 days. If a male died before the female, it was replaced by a male of the same age, which occurred once at 19 days of age in the frozen yeast group. Dishes were replaced daily and eggs were counted under binocular vision until day 21.

For each experiment, the mean daily number of eggs laid until day 21 or 23 was analysed with an ANOVA testing for the medium and age (repeated factor) effects and their interaction (flies dying or escaping before these ages were not taken into account, see Fig. 3). The no yeast group was not included in the analysis, because the egg-laying activity of these females was expected (and observed, see Fig. 3 and Le Rohellec and Le Bourg (2009) for similar results) to be very low.

\section{Longevity}

Two replicate experiments (TLS) involved vials with fresh or frozen live yeast, yeast being frozen ca 140 or 180 days before experiment, depending on the group of flies (respective groups 47/2014 and 1/2015: 5 or 6 vials of 15 flies for each sex and medium group). Mortality was checked daily and the results were analysed with an ANOVA testing the effect of sex, medium, replicate, and their interactions. Longevity data were squared to normalise residuals but very similar results were obtained with raw data.

\section{Climbing activity at various ages}

Flies were individually placed in a vertical vial (Falcon 2045) subjected to a mechanical stimulation (ca. 145 rpm during 3 s, Le Bourg, 2012) provided by a single-vial shaker and the highest height reached within $20 \mathrm{~s}$ after cessation of the stimulation was recorded. Climbing activity was observed (TLS) in the morning at 7, 14, 21, 28, 35, 41 and 49 days of age in crosssectional experiments (group 07/2015, 15 flies with intact legs in each sex and medium group). At the beginning of experiment live yeast was frozen for ca 230 days. Results were analysed with an ANOVA testing the effect of age, sex, medium, and their interactions.

\section{Survival of yeast cells after freezing}

The dye phloxine B is extruded by live yeast cells but not by dead cells, which allows to 
observe dead and live cells with a haematocytometer. The dye $(0.25 \mathrm{mg} / \mathrm{mL})$ was added either to fresh yeast, fresh yeast killed by heating, or yeast frozen for 9 months at $-12^{\circ} \mathrm{C}$ (TLS). A haemocytometer and a microscope were used to count cells one hour after adding the dye.

\section{Proliferation of live yeast}

Yeast cells were collected from fresh yeast, or from yeast frozen at $-12^{\circ} \mathrm{C}$ for ca 45 days or 13 months (TLS). Yeast cells were grown at $30^{\circ} \mathrm{C}$ in a continuously shaken vial containing a suspension of yeast in a liquid YPD medium (Yeast extract-Peptone-Dextrose medium, for one litre of distilled water, yeast extract: $10 \mathrm{~g}$, peptone: $20 \mathrm{~g}$, glucose-monohydrate: $20 \mathrm{~g}$ ). Phloxine B $(0.25 \mathrm{mg} / \mathrm{mL})$ was added $3 \mathrm{~min}$ before counting cells, which allowed one to separate coloured dead cells from live cells. Live and dead cells were counted each hour using a Neubauer chamber for $7 \mathrm{~h}$ after starting growth. Two experiments were done. In the first one, there was a high number of bacteria in the YPD medium and this is probably close to what is really observed in vials containing flies. In the second experiment, no bacteria were present, which is the routine procedure when cultivating cells.

\section{Metabolomic study of fresh and frozen yeast}

Frozen vials were stored one day at $25^{\circ} \mathrm{C}$ before using yeast (RNS). Yeast colony was collected on top of the medium with sterile plastic loop Ose needle, placed in $1.5 \mathrm{~mL}$ Eppendorf tubes, and dried in SpeedVac to standardise biomass (dry mass) in samples before extraction. Twenty $\mathrm{mg}$ of dry yeast were used in all samples for extraction following modified chloroform/methanol/water based protocols (Tambellini et al., 2013). Briefly, dry yeast was resuspended with $400 \mu \mathrm{L}$ of water, the content was vortexed and transferred to a $2 \mathrm{~mL}$ tube filled with two acid washed beads. Samples were bead beaten for $90 \mathrm{~s}$ (frequency 25/s) to break cell walls. Then, $600 \mu \mathrm{L} \mathrm{CHCl}{ }_{3} / \mathrm{MeOH}(1 / 2)$ were added directly to the cell lysate and vortexed twice for 2 min followed by centrifugation at 4,000 g for 5 min at $4^{\circ} \mathrm{C}$. The upper aqueous layer was isolated and transferred to a new microcentrifuge tube. Thirty microlitres of this aqueous fraction were dried down (SpeedVac) and stored at $-20^{\circ} \mathrm{C}$. The dry residue was resuspended in $30 \mu \mathrm{L}$ of $20 \mathrm{mg} \mathrm{mL} \mathrm{mL}^{-1}$ methoxyamine hydrochloride in pyridine before incubation under automatic orbital shaking at $40^{\circ} \mathrm{C}$ for $60 \mathrm{~min}$. Then, $30 \mu \mathrm{L}$ of MSTFA (N-Methyl-N(trimethylsilyl) trifluoroacetamide) were added and the derivatization was done at $40^{\circ} \mathrm{C}$ for 60 min under agitation (see Colinet et al., 2012). A CTC CombiPal autosampler (GERSTEL GmbH 
\& Co.KG, Mülheim an der Ruhr, Germany) was used, ensuring standardised sample preparation and timing. Metabolites were separated, identified and quantified using a GC/MS platform consisting of a Trace GC Ultra chromatograph and a Trace DSQII quadrupole mass spectrometer (Thermo Fischer Scientific Inc, Waltham, MA, USA). The oven temperature ranged from 70 to $170^{\circ} \mathrm{C}$ at $5^{\circ} \mathrm{C} \mathrm{min}{ }^{-1}$, from 170 to $280^{\circ} \mathrm{C}$ at $7^{\circ} \mathrm{C} \min ^{-1}$, from 280 to $320^{\circ} \mathrm{C}$ at $15^{\circ} \mathrm{C}$ $\mathrm{min}^{-1}$, and then the oven remained at $320^{\circ} \mathrm{C}$ for $4 \mathrm{~min}$. The injection order of the samples was completely randomised. All samples were run under the SIM mode rather than the full-scan mode. Only the 63 pure reference compounds included in our custom spectral database were screened. Calibration curves for 60 pure reference compounds at 5, 10, 20, 50, 100, 200, 500, 750, 1000, 1500 and $2000 \mu \mathrm{M}$ concentrations were run concurrently. Chromatograms were deconvoluted using XCalibur 2.0.7, and metabolite levels were quantified using the quadratic calibration curve for each reference compound and concentration.

For metabolomic data, a principal component analysis (PCA) was performed on the whole dataset to detect the compounds contributing the most to the separation between the two groups (fresh yeast vs frozen yeast). The inertia calculated in the PCA represents the part of the total variance that is due to the difference between modalities. Scaled data (i.e. mean-centred and divided by standard-deviation) were used in the multivariate analyses to prevent the effects of the metabolite concentration means and ranges of variability on the correlations with the principal components (PCs). This analysis was performed using the 'ade4' library of the $\mathrm{R}$ statistical software R 2.13.0 (R Core team, 2013).

\section{Protein dosage}

The total protein contents of three different treatments were compared: 1) fresh live yeast diluted in distilled water and stored at $4^{\circ} \mathrm{C}$ for $24 \mathrm{~h}$ before extraction (i.e. absence of nutrient source), 2) fresh live yeast diluted in distilled water and then placed at the surface of the medium in petri dishes containing RNS media for $24 \mathrm{~h}$ at $4^{\circ} \mathrm{C}$ for before extraction, 3) live yeast placed at the surface of the RNS medium of petri dishes and stored at $-20^{\circ} \mathrm{C}$. The dosage was replicated thrice: after 86, 151 and 175 days of congelation at $-20^{\circ} \mathrm{C}$ with 4 replicates for each assay $(\mathrm{n}=4)$. Yeast colony was collected and placed in $1.5 \mathrm{~mL}$ Eppendorf tubes and dried in SpeedVac to standardise dry mass. Dry pellets were precisely weighted (Mettler Toledo UMX2, accurate to $0.001 \mathrm{mg}$ ) and $10 \mathrm{mg}$ of dry pellet were used for extraction with $200 \mu \mathrm{L}$ of lysis 
buffer solution (100 mM KH $\mathrm{KH}_{4}, 1 \mathrm{mM}$ EDTA, pH 7.4). The content was vortexed and snapfrozen in $\mathrm{N}_{2}$ and then directly thawed to break cell walls before they were bead-beaten with two tungsten beads for $90 \mathrm{~s}$ (frequency 25/s). The homogenates were then subjected to low-spin centrifugation ( $500 \mathrm{~g}, 5 \mathrm{~min}, 4^{\circ} \mathrm{C}$ ) to allow gentle sedimentation cells debris and $5 \mu \mathrm{L}$ of clear supernatant were transferred (in duplicate) into a 96-well microplate, together with $250 \mu \mathrm{L}$ of Bradford micro-assay reagent (B6916; Sigma, France) for total protein quantification at $595 \mathrm{~nm}$ (VersaMax ${ }^{\mathrm{TM}}$ Microplate Reader, Molecular devise). Quantification was based on a BSA standard curve. A two-way ANOVA was used to compare mean protein contents with the treatment and the replicates as crossed factors.

\section{SDS-PAGE}

We used SDS-PAGE to allow direct visualisation of yeast protein profiles and detect a possible degradation during freezing treatment of yeast. Three treatments were compared - Lane A: protein extract from fresh live yeast, Lane B: protein extract from frozen yeast (stored at -20 - C for 175 days) and Lane C: protein extract digested with trypsin (V511A, Promega) to visualise a digested protein profile. Protein concentrations in extracts were adjusted to $5 \mu \mathrm{g}$ of protein and were mixed with NuPAGE® LDS (4 x) sample buffer (Life Technologies) and DTT (50mM). The mix was heated on dry block at $80^{\circ} \mathrm{C}$ for $10 \mathrm{~min}$. Samples were then applied to precast NuPAGE® $12 \%$ Bis-Tris polyacrylamide gel (Life Technologies). NuPAGE® MES SDS (20 $\mathrm{x}$ ) was used as running buffer (Life Technologies) to resolve small molecular weight proteins. SDS-PAGE was then performed at $200 \mathrm{~V}$ for $40 \mathrm{~min}$. After electrophoresis, gels were stained with EZBlue ${ }^{\mathrm{TM}}$ Coomassie Brilliant Blue G-250 (Sigma Aldrich). Unstained natural protein standard was used as a molecular weight marker.

\section{Results}

\section{Starvation resistance}

Females survived longer than males $(\mathrm{F}(1,634)=1422.00, \mathrm{p}<0.0001,99.04 \pm 1.70 \mathrm{~h}$ vs $36.70 \pm 0.56 \mathrm{~h}$ ). Flies fed with frozen yeast had a lower starvation resistance than those fed with fresh yeast (Fig. 1, F $(1,634)=59.15, \mathrm{p}<0.0001$ ) and this effect was mainly due to females ( sex by medium interaction: $\mathrm{F}(1,634)=34.85, \mathrm{p}<0.0001$, females, respectively: $88.22 \pm 2.18$ vs $110.13 \pm 2.31 \mathrm{~h}$; males: $35.05 \pm 0.86$ vs $38.39 \pm 0.71 \mathrm{~h})$. The replicate effect was not 
significant ( $F$ close to 1$)$, but the sex by replicate interaction $(F(2,634)=6.51, p=0.0016)$ showed that there was no replicate-linked difference in females (groups 41/2014, 45/2014, 46/2014: $99.10 \pm 3.74,100.70 \pm 2.93,97.34 \pm 2.32 \mathrm{~h}$ ), by contrast to what was observed in males $(34.50 \pm 0.72,32.46 \pm 0.73,42.83 \pm 1.05 \mathrm{~h})$. The medium by replicate interaction was not significant ( $F$ close to 1) and the second-order interaction between sex, medium and replicate was nearly significant $(\mathrm{F}(2,634)=2.85, \mathrm{p}=0.0587)$. To sum up, flies fed with frozen yeast had a lower starvation resistance than flies fed with fresh yeast, and this effect was mainly due to females.

\section{Resistance to cold}

In the experiment done in the TLS lab, males better survived than females after $24 \mathrm{~h}$ at 0 - $\mathrm{C}(\mathrm{F}(1,433)=34.45, \mathrm{p}<0.0001,30.9 \%$ vs $7.26 \%)$. The medium and replicate factors and all interactions were not significant. Thus, frozen yeast neither increased nor decreased resistance to cold in this experiment. The same results were observed in the experiment observing survival after $24 \mathrm{~h}$ at $0^{\circ} \mathrm{C}$ done in the RNS lab $(\mathrm{Fs}<1)$, but the interaction between sex and medium was nearly significant $(F(1,196)=3.48, \mathrm{p}=0.0635)$, indicating that females with frozen yeast had a tendency to better survive than those with fresh yeast (70 vs 54\%), while the contrary was observed in males (56 vs 66\%).

In the second experiment done in the RNS lab $\left(-3.5^{\circ} \mathrm{C}\right.$ for 90 or $\left.120 \mathrm{~min}\right)$, it was impossible to compute the second-order interaction in the logistic model because there was not any death in one group. Males better survived than females $(F(1,393)=9.28, p=0.0025,59.5$ vs $68 \%)$ and flies fed with fresh yeast better survived than those fed with frozen yeast $(\mathrm{F}(1,393)$ $=28.93, \mathrm{p}<0.0001,78.5 \mathrm{vs} 49 \%$ ) and this effect was mainly due to females (sex by medium interaction: $\mathrm{F}(1,393)=5.66, \mathrm{p}=0.0178$, females: 84 vs $35 \%$, males: 73 vs $63 \%)$. The percentage of survivors was lower when the cold stress was 120 min long $(F(1,393)=37.20$, p < 0.0001, 81\% with the 90 min stress and $46.5 \%$ with the 120 min one) and this effect was more important in males (stress length by sex interaction: $\mathrm{F}(1,393)=24.71, \mathrm{p}<0.0001$, males: 98 vs 38\%, females: 64 vs 55\%). The medium by stress length interaction was not significant (F close to 1).

To sum up, feeding on frozen or fresh yeast had no effect on survival after a 24 h stay at 0 - C, but a higher survival of flies feeding on fresh yeast was observed if they spent 90 or 120 min at $-3.5^{\circ} \mathrm{C}$, and this effect was more important in females. 


\section{Resistance to heat}

In the first experiment, females better survived than males $(F(1,302)=91.82, p<0.0001$, 71.4 vs $8.2 \%$ ). The medium factor and its interaction with sex were not significant (Fs close to 1 ). Flies better survived to heat in the second experiment and the sex effect was less important, females still surviving better than males $(\mathrm{F}(1,291)=29.96, \mathrm{p}<0.0001,89.0$ vs $61.0 \%)$. The medium factor and its interaction with sex were not significant (Fs close to 1). Therefore, these two experiments show that feeding on frozen or fresh yeast had no effect on survival to heat.

\section{Fecundity}

In the experiment with virgin females, the medium effect was not significant (F close to 1, 10 females in each group: 2 females escaped or died in the fresh and frozen yeast groups, respectively) and the laying activity varied with age (Fig. 2, $\mathrm{F}(22,396)=12.74, \mathrm{p}<0.0001$ ), increasing up to 60 eggs a day at ca 15 days of age and decreasing thereafter. The interaction between age and medium factors was not significant ( $F$ close to 1 ). Thus, the egg-laying activity was similar with fresh or frozen yeast at all ages. However, virgin females have a low egg-laying activity when compared to mated females (see Le Rohellec and Le Bourg, 2009), and one can hypothesise that the quality of yeast is not an issue if egg-laying is low. By contrast, mated females lay heavily and a low quality of yeast could limit their egg-laying. Therefore, studying mated females is of interest.

In the experiment with mated females, the medium effect was not significant, but there was a tendency for a lower laying activity in the frozen yeast group $(F(1,17)=2.81, p=0.1123,10$ and 9 females in the fresh and the frozen yeast groups, respectively: 2 females of the fresh yeast group escaped and 3 ones died in the frozen yeast group). The laying activity varied with age (Fig, $\mathrm{F}(20,340)=103.93, \mathrm{p}<0.0001)$, increasing up to 110 eggs a day at young age before beginning to decrease. The interaction between age and medium showed that the laying activity was similar in both groups at young age but lower at older ages in females fed on frozen yeast (Fig.2, $\mathrm{F}(20,340)=6.37, \mathrm{p}<0.0001)$. Therefore, frozen yeast limited egg-laying after a few days.

\section{Longevity}

Males lived longer than females $(\mathrm{F}(1,679)=10.70, \mathrm{p}=0.0011$, means $\pm \mathrm{SEM}: 49.46 \pm$ 0.54 vs $46.59 \pm 0.62$ days $)$. The interaction between medium and $\operatorname{sex}(\mathrm{F}(1,679)=4.83, \mathrm{p}=$ 
0.0282) showed that males fed with frozen yeast lived slightly less than males fed with fresh yeast (47.97 \pm 0.79 vs $51.02 \pm 0.71$ days), no medium effect being observed in females (46.71 \pm 0.89 vs $46.47 \pm 0.85$ days, respectively for frozen and fresh yeast groups). The other factors and interactions were not significant. Therefore, males fed with frozen yeast lived slightly shorter than those fed with fresh yeast.

\section{Climbing activity at various ages}

Flies fed with frozen yeast had slightly higher scores than those fed with fresh one (Fig. 3, $\mathrm{F}(1,392)=4.85, \mathrm{p}=0.0283$, means $\pm \mathrm{SEM}: 5.93 \pm 0.28$ vs $5.20 \pm 0.29 \mathrm{~cm})$ and scores decreased with age $(F(6,392)=27.38, \mathrm{p}<0.0001)$. The sex by medium interaction showed that females got higher scores than males when young while the contrary was observed at old ages $(\mathrm{F}(6,392)=4.70, \mathrm{p}<0.0001)$. The age by medium interaction showed that flies fed with frozen yeast had higher scores than those fed with fresh yeast, except in 3 and 4 -week-old flies $(F(6$, $392)=4.15, p=0.0005)$. The sex effect and the other interactions were not significant. Thus, on the whole, flies fed with frozen yeast had higher climbing scores than flies fed with fresh yeast.

\section{Survival of yeast cells after freezing}

Figure 4 shows pictures of yeast coloured by the dye phloxine B at a concentration of 0.25 $\mathrm{mg} / \mathrm{mL}$. Yeast cells killed by heating (top) are coloured, while live cells are not coloured (middle). About $50 \%$ of frozen cells were coloured (bottom), which shows that freezing killed ca half of the cells.

\section{Proliferation of live yeast}

Figure 5 shows concentrations of live cells up to $7 \mathrm{~h}$ after being transferred to $30^{\circ} \mathrm{C}$. The percentage of dead cells at the first count was, respectively for the first (with bacteria) and second (without bacteria) experiments, 2 and $0 \%$ for fresh yeast, 54 and $62 \%$ for the yeast frozen for 45 days, 71 and $75 \%$ for the yeast frozen for 13 months, and the concentration of dead cells did not clearly vary during the $7 \mathrm{~h}$ of observation (data not shown). Therefore, as also shown in Figure 3, many cells did not survive freezing. When cells were grown with bacteria in flasks, frozen cells had a low proliferation (Fig. 5, top). When grown without bacteria, yeast cells frozen for 45 days better proliferated than those frozen for 13 months (Fig. 5, bottom). However, frozen cells had a lower proliferation than fresh yeast cells, whatever the freezing duration could be. 


\section{Metabolomic profiles of fresh vs frozen yeast}

Among the 63 metabolites included in our spectral library, 40 were detected in our samples. We found 15 free amino acids, 6 sugars, 10 polyols, 7 metabolic intermediates and two other metabolites (see Table S1 for compound list and abbreviations). The metabolic profiles of control fresh vs frozen yeast showed that a number of metabolites had their concentrations altered, which resulted in contrasted metabotypes between the two groups (Fig. 6, top). A clearcut separation was observed along the first principal component (PC1) of the PCA, which accounted for $76.4 \%$ of the total inertia (Fig. 6, top). Free amino acids such as Leu, Phe, Ile, Val, Met, Thr, Asp, Ser and Gly were the molecules the most positively correlated to PC1 (i.e. they accumulated in frozen yeast), whereas on the opposite side the sugar trehalose and intermediate acidic metabolites such as pipecolate, fumarate, malate and citrate were the molecules the most negatively correlated to PC1 (i.e. they were less observed in frozen yeast) (Fig. 6, bottom). The other principal components accounted for only 14.7\% (PC2) and 3.5\% (PC3) of the total inertia and mainly represented within-treatment variations. The most striking variations observed between the two treatments were trehalose which showed a 73-fold reduction in frozen yeast, and some free amino acids (Met, Leu, Tyr) and glycerol which accumulated up to 10-fold in frozen yeast (See suppl Fig S1).

\section{Total protein content}

The protein content was higher in the frozen yeast treatment group, intermediate in the group with fresh yeast extract placed on medium and the lowest in the group with fresh live yeast diluted in distilled water $(\mathrm{F}(2,27)=23.86, \mathrm{p}<0.0001$, Fig. 7$)$. The total protein content varied according to the replicate $(F(2,27)=11.12, \mathrm{p}=0.0003)$ and there was no significant interaction between the treatment and replicate factors.

\section{$S D S-P A G E$}

The work described here was initiated as part of an investigation of the degradation of yeast proteins extract, defined in terms of the low level degradation products (breakdown intermediates), potentially occurring during freezing period. Visual inspection of the gels (Fig. 8) revealed that even if the profiles of lanes A (fresh yeast extract) and B (frozen yeast extract) were rather similar, slight differences were observed. For instance, some bands observed in lane A in the higher than $55 \mathrm{kDa}$ molecular weights disappeared in lane B, or appeared fainter in lane 
B than in lane A. In contrast, new bands of intermediate or small molecular weights $(\sim 35$ and 6 kDa) appeared in lane B. Finally, a large and light smearing zone appeared in the lower than 14 $\mathrm{kDa}$ molecular weights in lane B; a similar smearing light zone was observed in trypsin-digested extract (lane C).

\section{Discussion}

The effect of freezing on yeast cells: is frozen yeast a low-quality food?

The effects of freezing on yeast are summarised in Table 1. The percentage of dead cells in frozen yeast was much more important than in fresh yeast (Fig. 4, 50-75\% vs ca 2\%, depending on the freezing duration) and the proliferation of surviving frozen cells was low (Fig. 5). In addition, metabolic intermediates such as pipecolate, fumarate, malate and citrate (i.e. tricarboxylic acid cycle) were at lower concentration in frozen yeast (Fig. 6 bottom). The whole picture likely represents a degenerative symptom of freezing stress: a lower amount of live yeast cells that are less metabolically active.

In addition, the metabolomic study also shows that frozen yeast contained a higher amount of free amino acids and a lower amount of the disaccharide trehalose than fresh yeast. A low amount of trehalose after freezing has been linked to a decrease in cell viability (Nakamura et al., 2009) and yeast cells have a higher survival to freezing in the presence of exogenous trehalose, a well-known cryoprotectant (Diniz-Mendes et al., 1999). Trehalose is often considered to be a major reserve carbohydrate accumulating during starvation conditions, but this role has been criticised (Werner-Washburne et al., 1993; Wiemken, 1990). It could be that frozen cells in our experiments poorly survived to freezing because of a lower concentration of trehalose than in fresh cells. At variance with this conclusion, frozen cells accumulated glycerol (Fig. 6, bottom), another cryoprotectant that is however less efficient than trehalose (Shi et al., 2014).

The accumulation of free amino acids in frozen cells could reflect two different processes: a protective role because some amino acids such as Pro, Glu, arginine (Arg), and Asp have a cryoprotective function (Shi et al., 2014), or a degenerative symptom because accumulation of free amino acids could be linked to the degradation of proteins. In accordance with a cryoprotective role of such an accumulation, proline and Asp were more observed in frozen cells than in fresh ones (Fig. 6, bottom), but glutamic acid was more present in fresh cells and many 
other free amino acids were more observed in frozen cells (Fig. 6, bottom): the balance is in favour of a degradation of proteins in frozen cells. In order to confirm this hypothesis, we measured total protein content with the Bradford dye that binds to proteins or peptides bigger than 3kDa but not to free amino acids (Congdon et al., 1993). The protein content was higher in frozen cells (Fig. 7) and this could be due to protein fragments or peptides heavier than 3kDa, because intracellular protein degradation requires a sequential series of proteolytic events that result in the conversion of the native protein into free amino acids, but this process is preceded by production of intermediate, partially-proteolysed forms (Reznick et al., 1985). To confirm further the hypothesis of a degradation of proteins in frozen cells, we used SDS-PAGE (Fig. 8) to detect a differential protein profile between fresh and frozen yeasts. Only light changes were detected in the profiles but, interestingly, there was a potential indication of protein degradation, because a light smearing zone in the small molecular weights portion of the gel $(<$ $14 \mathrm{kDa}$ ) was observed, as in the trypsin-digested extract that contains only small peptides from digested proteins. This zone could be made of degraded products of proteins or degraded polypeptides, as in as in trypsin-digested extract, and this could also contribute to increase the Bradford signal, provided molecular weight is higher than $3 \mathrm{kDa}$ (Fig. 7). Taken together, we found increases in free amino acids (Fig. 6, bottom), in Bradford signal (Fig. 7), and potential presence of degraded products of proteins (Fig. 8).

The whole picture of the study of frozen yeast suggests that the bulk of proteins that constitutes yeast protein extract might be partially degraded when frozen for extended periods, and thus potentially of lower nutritional quality for flies. However, it is important to stress that we cannot distinguish whether the physiological metrics observed (amino acids, strong reduction of trehalose, more proteins, more glycerol, and so on) are a direct consequence of freezing (i.e. a degenerative symptom of stress in dying cells) or a protective mechanism implemented in surviving yeast cells: it is maybe a combination of both processes.

To sum up, comparing fresh and frozen yeast seems to confirm that frozen yeast is a low quality food.

\section{The effects of frozen yeast on flies}

It is now known that the P:C ratio can modify lifespan of flies and that the reported effects of dietary restriction (DR) in this species are better explained by this ratio rather than by the 
caloric intake (see the Introduction section). In some experiments the P:C ratio is fixed by the experimenter: each group of flies is given food with a fixed P:C ratio (e.g. Lee et al., 2008; Vigne and Frelin, 2010; Lushchak et al., 2012; Bruce et al., 2013). Other experiments propose a choice between capillaries with liquid diets containing proteins/amino acids (e.g. yeast) and/or carbohydrates (e.g. Vigne and Frelin, 2010; Fanson et al., 2012; Lee et al., 2013; Jensen et al., 2015), and flies select the P:C ratio by modulating their intake at each capillary. Flies feeding on a medium with live yeast added at the surface of the medium can eat the quantity of live yeast they want and thus select their P:C ratio by modulating this intake. Therefore, comparing flies with or without live yeast at the surface of the medium, as in Le Rohellec and Le Bourg (2009), compares flies free to select their P:C ratio to flies that can only eat the dead yeast mixed in a fixed proportion with the other components of the medium.

The present study is not a DR experiment, because it compares flies free to eat any quantity of live yeast deposited at the surface of the medium, live yeast being of a standard quality (fresh yeast) or expected to be of a low quality (frozen yeast), because freezing has deleterious effects on yeast cells (see above). Rather, this experiment is an attempt to test whether it is possible to design a surrogate of low-quality food in flies. Like in a cafeteria, flies can modulate their feeding by avoiding eating a too high amount of frozen yeast, because live yeast is deposited at the surface of the medium. However, as it is the only available live yeast, they could nevertheless be led to eat some quantity of this low quality yeast. These experiments were not concerned with the precise measurement of consumed live yeast but simply tested what happens when flies are offered what is expected to be a low quality food. Therefore, as in a cafeteria, flies can partly modulate the food they eat, but only to a certain extent as the choice is limited by the experimenter: fresh or frozen yeast added at the surface of the same rearing medium.

The effects of frozen yeast on flies are summarised in Table 2. Flies fed with frozen yeast had a lower resistance to starvation (mainly in females) and to an acute cold stress (to a higher extent in females than in males) than flies with fed fresh yeast. Males had also a slightly lower longevity and mated females had a lower fecundity than those fed with fresh yeast. By contrast, flies fed with frozen yeast had higher climbing scores, except at middle age, and frozen yeast had no effect on resistance to heat. Removing live yeast (Le Rohellec and Le Bourg, 2009) provided 
similar but more important effects to those of feeding on frozen yeast. For instance, feeding on frozen yeast has less important effects on fecundity than removal of live yeast (Fig. 2, see also Fig. 1 in Le Rohellec and Le Bourg 2009). By contrast, flies fed with frozen yeast had higher climbing scores than those with fresh yeast, except at middle age, while flies without live yeast had higher climbing scores if older than 2 weeks (Fig. 8 in Le Rohellec and Le Bourg, 2009). However, as these authors did not study climbing scores in flies older than 4 weeks of age while the present study involved 1-7-week-old flies, it is somewhat difficult to compare the two studies.

Therefore, frozen yeast could be equivalent either to a too low quantity of fresh yeast or to a low quality yeast. If a too low quantity of fresh yeast were the best explanation, we should have observed deleterious effects from the very beginning, because essential nutrients would be lacking, but there was a delay before observing a fecundity decrease in mated females and no effect was observed in virgin females (Fig. 2). By contrast, virgin or mated females fed without live yeast (no yeast groups on Fig. 2) had a low fecundity throughout life.

There is however another hypothesis to explain our results. Frozen yeast contains more free amino acids and less carbohydrates (Table 1), and a higher total amount of proteins (Fig. 7) than fresh yeast, which shows that the P:C ratio of frozen yeast is higher than that of fresh one. As males fed on frozen yeast lived slightly less than those fed on fresh one (48 vs 51 days), one could conclude that a high $\mathrm{P}: \mathrm{C}$ ratio is the best explanation of this result because a high $\mathrm{P}: \mathrm{C}$ ratio decreases longevity of males (Jensen et al., 2015). However, feeding on frozen live yeast decreased late fecundity and had no effect on longevity of virgin females, while a high P:C ratio increases fecundity and decreases lifespan of both sexes (e.g. Lee et al., 2008; Lushchak et al., 2012; Jensen et al., 2015). Therefore, while both a high P:C ratio (Lee et al., 2008) and frozen live yeast decrease resistance to starvation, fecundity and longevity results seem not to be only explained by a high P:C ratio in frozen yeast. Therefore, a modified P:C ratio could only partly explain our results.

On the whole, flies appear to suffer from feeding on frozen yeast, even if these effects are not tragic: flies are still able to reproduce and to live fairly long, but their resistance to acute stresses is severely impaired. The seemingly positive result of feeding on frozen yeast could in fact reflect a deleterious effect of frozen yeast, because starved flies are known to have a high 
activity level (e.g. Connolly, 1966). While frozen yeast thus does not kill flies, it remains that feeding on frozen yeast has some deleterious effects, despite the fact that flies can also feed on the corn medium that is identical for all flies. This seems to indicate that even a part of nutrients coming from non-optimal food can have negative effects on healthspan.

This study thus indicates that, beyond the number of calories and the P:C ratio, it could be important to take into account the quality of food in nutritional studies of flies. While this conclusion is not original in human studies because there is no debate on the need to favour high-quality products rather than low ones, for instance replacing trans-unsaturated fat known to increase cardiovascular risk (Hu et al., 1997), it seems that studies of nutritional quality in flies are scarce, to say the very least. Feeding flies with frozen yeast could thus provide a model of a low-quality food in flies.

\section{Acknowledgements}

We are grateful to David Renault and Blandine Charoy (University Rennes-1) for their assistance in some experiments on yeast. 


\section{References}

Bruce, K.D., Hoxha, S., Carvalho, G.B., Yamada, R., Wang, H.D., Karayan, P., He, S., Brummel, T., Kapahi, P., Ja, W.W., 2013. High carbohydrate-low protein consumption maximizes Drosophila lifespan. Exp Geront 48, 1129-1135.

Chippindale, A.K., Leroi, A.M., Kim S.B., Rose, M.R., 1993. Phenotypic plasticity and selection in Drosophila life-history evolution. I. Nutrition and the cost of reproduction. J Evol Biol 6, 171-193.

Colinet, H., Larvor, V., Laparie, M., Renault, D., 2012. Exploring the plastic response to acclimation through metabolomics. Funct Ecol 26, 711-722.

Colinet, H., Renault D., 2014. Dietary live yeast alters metabolic profiles, protein biosynthesis and thermal stress tolerance of Drosophila melanogaster. Comp Biochem Physiol A Mol Integr Physiol 170, 6-14.

Colman, R.J., Beasley, T.M., Kemnitz, J.W., Johnson, S.C., Weindruch, R., Anderson, R.M., 2014. Caloric restriction reduces age-related and all-cause mortality in rhesus monkeys. Nat Commun 5, 3557.

Congdon, R.W., Muth, G.W., Splittgerber, A.G., 1993. The binding interaction of Coomassie Blue with proteins. Analyt Biochem 213, 407-413.

Connolly, K.J., 1966. Locomotor activity in Drosophila as a function of food deprivation. Nature 209, 224.

David, J., Clavel, M.F., 1968. A new method for measuring egg production without disturbing the flies. Drosophila Inform Serv. 43, 182-183.

Diniz-Mendes, L., Bernardes, E., de Araujo, P.S., Panek, A.D., Paschoalin, V.M.F., 1999. Preservation of frozen yeast cells by trehalose. Biotechnol Bioeng 65, 572-578.

Fanson, B.G., Yap, S., Taylor, P.W., 2012. Geometry of compensatory feeding and water consumption in Drosophila melanogaster. J Exp Biol 215, 766-773.

Greer, E.L., Brunet, A., 2009. Different dietary restriction regimens extend lifespan by both independent and overlapping genetic pathways in C. elegans. Aging Cell 8, 113-127.

Hu, F.B., Stampfer, M.J., Manson, J.E., Rimm, E., Colditz, G.A., Rosner, B.A., Hennekens, C.H., Willett, W.C., 1997. Dietary fat intake and the risk of coronary heart disease in women. N Engl J Med 337, 1491-1499. 
Hulström, M., 2015. Caloric restriction reduces age-related but not all-cause mortality. Acta Physiol 214, 3-5.

Jensen, K., McClure, C., Priest, N.K., Hunt, J., 2015. Sex-specific effects of protein and carbohydrate intake on reproduction but not lifespan in Drosophila melanogaster. Aging Cell, in press.

Kalmus, H., 1943. A factorial experiment on the mineral requirements of a Drosophila culture. Am Nat 77, 376-380.

Le Bourg, E., 2010. Predicting whether dietary restriction would increase longevity in species not tested so far. Ageing Res Rev 9, 289-297.

Le Bourg, E., 2012. Combined effects of two mild stresses (cold and hypergravity) on longevity, behavioral aging, and resistance to severe stresses in Drosophila melanogaster. Biogerontology 13, 313-328.

Le Bourg, E., Minois, N., 1996. Failure to confirm increased longevity in Drosophila melanogaster flies submitted to a food restriction procedure. J. Geront Biol Sci 51A, B280B283.

Le Bourg E., Minois N. (2005) Does dietary restriction really increase longevity in Drosophila melanogaster? Ageing Res Rev 4, 409-421.

Lee, K.P., Kim, J.S., Min, K.J., 2013. Sexual dimorphism in nutrient intake and life span is mediated by mating in Drosophila melanogaster. Anim Behav 86, 987-992.

Lee, K.P., Simpson, S.J., Clissold, F.J., Brooks, R., Ballard, J.W.O., Taylor, P.W., Soran, N., Raubenheimer, D., 2008. Lifespan and reproduction in Drosophila: new insights from nutritional geometry. Proc Natl Acad Sci USA 105, 2498-2503.

Le Rohellec, M., Le Bourg, E., 2009. Contrasted effects of suppressing live yeast from food on longevity, aging and resistance to several stresses in Drosophila melanogaster. Exp Geront 44, 695-707.

Liao, C.Y., Rikke, B.A., Johnson, T.E., Diaz, V., Nelson, J.F., 2010. Genetic variation in the murine lifespan response to dietary restriction: from life extension to life shortening. Aging Cell 9, 92-95.

Lushchak, O.V., Gospodaryov, D.V., Rovenko, B.M., Glovyak, A.D., Yurkevych, I.S., Klyuba, V.P., Shcherbij, M.V., Lushchak, V.I., 2012. Balance between macronutrients affects life 
span and functional senescence in fruit fly Drosophila melanogaster. J Gerontol A Biol Sci Med Sci 67, 118-125.

Mattison, J.A., Roth, G.S., Beasley, T.M., Tilmont, E.M., Handy, A.M., Herbert, R.L., Longo, D.L., Allison, D.B., Young, J.E., Bryant, M., Barnard, D., Ward, W.F., Qi, W., Ingram, D.K., de Cabo, R., 2012. Impact of caloric restriction on health and survival in rhesus monkeys from the NIA study. Nature 489, 318-321.

Nakamura, T., Takagi, H., Shima, J., 2009. Effects of ice-seeding temperature and intracellular trehalose contents on survival of frozen Saccharomyces cerevisiae cells. Cryobiology 58, $170-174$.

R core team, 2013. R: a language and environment for statistical computing. http://www. Rproject.org.

Ramsey, J.J., Harper, M.H., Weindruch, R., 2000. Restriction of energy intake, energy expenditure, and aging. Free Rad Biol Med 29, 946-968.

Reznick, L., Rosenfelder, S., Shpund, S., Gershon, D., 1985. Identification of intracellular degradation intermediates of aldolase B by antiserum to the denatured enzyme. Proc Natl Acad Sci USA 82, 6114-6118.

Shi, X., Miao, Y., Chen, J.Y., Chen, J., Li, W., He, X., Wang, J., 2014. The Relationship of freeze tolerance with intracellular compounds in baker's yeasts. Appl Biochem Biotechnol 172, 3042-3053.

Solon-Biet, S.M., McMahon, A.C., Ballard, J.W., Ruohonen, K., Wu, L.E., Cogger, V.C., Warren, A., Huang, X., Pichaud, N., Melvin, R.G., Gokarn, R., Khalil, M., Turner, N., Cooney, G.J., Sinclair, D.A., Raubenheimer, D., Le Couteur, D.G., Simpson, S.J., 2014. The ratio of macronutrients, not caloric intake, dictates cardiometabolic health, aging, and longevity in ad libitum-fed mice.Cell Metab 19, 418-430.

Tambellini, N.P., Zaremberg, V., Turner, R.J., Weljie, A.M., 2013. Evaluation of extraction protocols for simultaneous polar and non-polar yeast metabolite analysis using multivariate projection methods. Metabolites 3, 592-605.

Vigne, P., Frelin, C., 2007a. Diet dependent longevity and hypoxic tolerance of adult Drosophila melanogaster. Mech Ageing Dev 128, 401-406.

Vigne, P., Frelin, C., 2007b. Plasticity of the responses to chronic hypoxia and dietary 
restriction in an aged organism: evidence from the Drosophila model. Exp Geront 42, $1162-1166$.

Vigne, P., Frelin, C., 2010. Food presentation modifies longevity and the beneficial action of dietary restriction in Drosophila. Exp Geront 45, 113-118.

Werner-Washburne, M., Braun, E., Johnston, G.C., Singer, R.A., 1993. Stationary phase in the yeast Saccharomyces cerevisiae. Microbiol Rev 57, 383-401.

Wiemken, A., 1990. Trehalose in yeast, stress protectant rather than reserve carbohydrate. Antonie Leeuwenhoek 58, 209-217.

Zajitschek, F., Zajitschek, S.R., Friberg, U., Maklakov, A.A., 2013. Interactive effects of sex, social environment, dietary restriction, and methionine on survival and reproduction in fruit flies. Age 35, 1193-1204. 


\section{Table 1}

Summary of the effects of freezing on yeast. A plus sign indicates the abundance of metabolites and other molecules, and a zero sign a very low abundance. If the abundance is more important in fresh or frozen yeast, the plus sign is duplicated.

\begin{tabular}{|l|c|c|}
\hline & Fresh yeast & Frozen yeast \\
\hline Percentage of dead cells & $0-2 \%$ & $\begin{array}{c}54-62 \% \text { (frozen for 45 days) } \\
71-75 \% \text { (frozen for 13 months) }\end{array}$ \\
\hline Cellular proliferation & High & $\begin{array}{c}\text { Low (frozen for 45 days) } \\
\text { Very low (frozen for 13 } \\
\text { months) }\end{array}$ \\
\hline $\begin{array}{l}\text { Metabolomic study: free amino } \\
\text { acids }\end{array}$ & + & ++ \\
\hline $\begin{array}{l}\text { Metabolomic study: sugars } \\
\text { (glucose, trehalose) }\end{array}$ & + & 0 \\
\hline Metabolomic study: polyols & 0 & + \\
\hline
\end{tabular}

\section{Table 2}

Summary of the effects of frozen yeast on longevity, fecundity, climbing activity and resistance to various stresses. A minus sign indicates a deleterious effect of frozen yeast (e.g. a lower resistance to starvation), a plus sign a positive effect, and a zero an absence of effect. If the effects are more important in one sex, the sign is duplicated in this sex.

\begin{tabular}{|l|c|c|}
\hline & Males & Females \\
\hline Starvation resistance & - & - \\
\hline Resistance to cold (24 h at & 0 & 0 \\
$\left.0^{\circ} \mathrm{C}\right)$ & - & - \\
\hline Resistance to cold (90 or 120 & & \\
min at $\left.-3.5^{\circ} \mathrm{C}\right)$ & 0 & 0 \\
\hline Resistance to heat $(90$ min at & & \\
$\left.37^{\circ} \mathrm{C}\right)$ & & \\
\hline
\end{tabular}




\begin{tabular}{|l|c|c|} 
Fecundity (virgin females) & 0 \\
\hline Fecundity (mated females) & & $\begin{array}{c}\text { 0 (at young age) } \\
- \text { (at older ages) }\end{array}$ \\
\hline Longevity & - & 0 \\
\hline Climbing activity at various & + & + \\
\hline ages & & \\
\hline
\end{tabular}

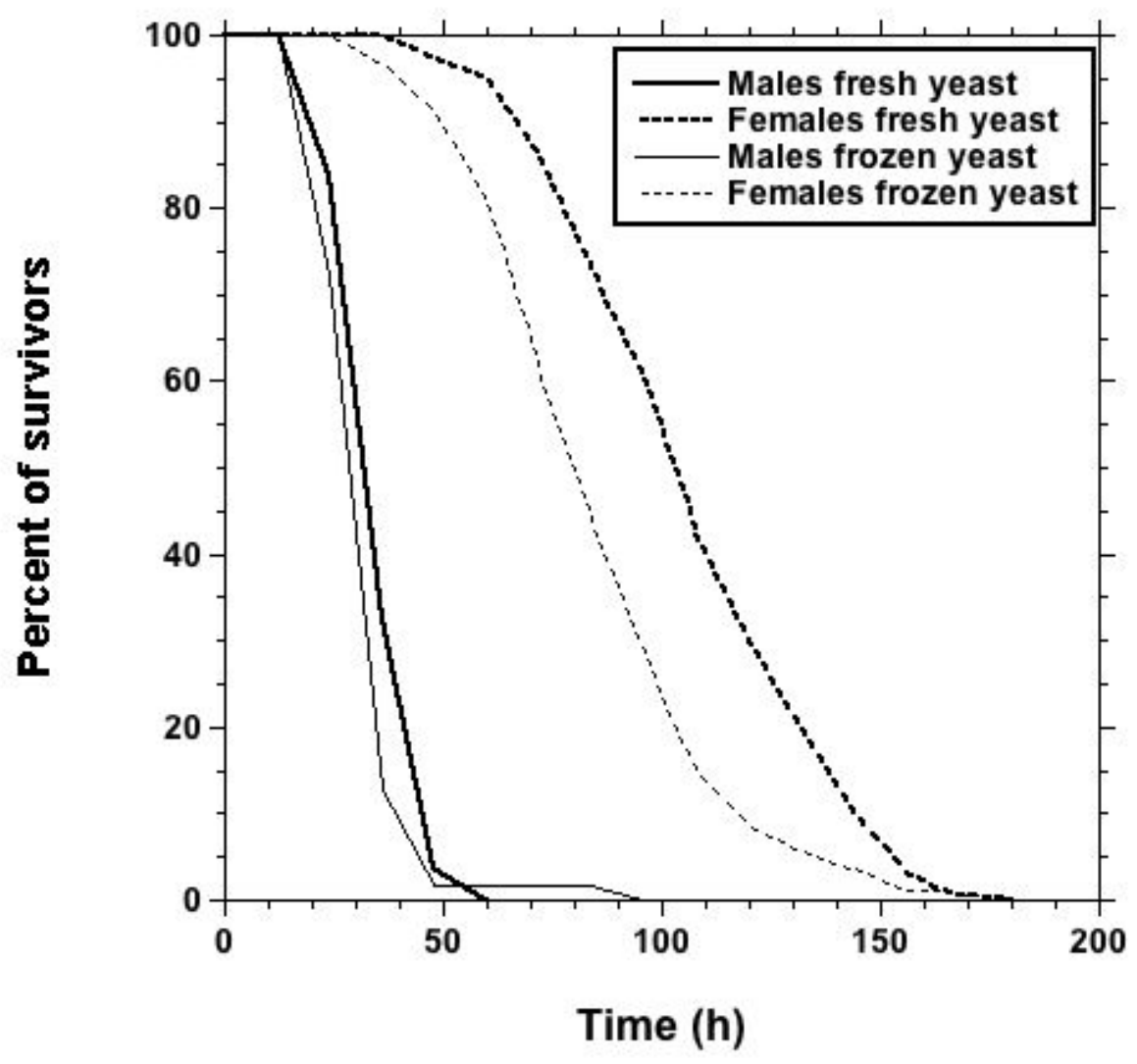

Figure 1. Starvation resistance of flies fed with fresh or frozen live yeast deposited at the surface of the medium ca one hour before using the vials. Flies were transferred into vials containing a medium only made of agar at 12 days of age and survival was observed with a $12 \mathrm{~h}$ interval up to the death of the last fly. Males: fresh yeast, $n=161$; frozen yeast, $n=165$. Females: fresh yeast, $n=158$; frozen yeast, $n=162$. 


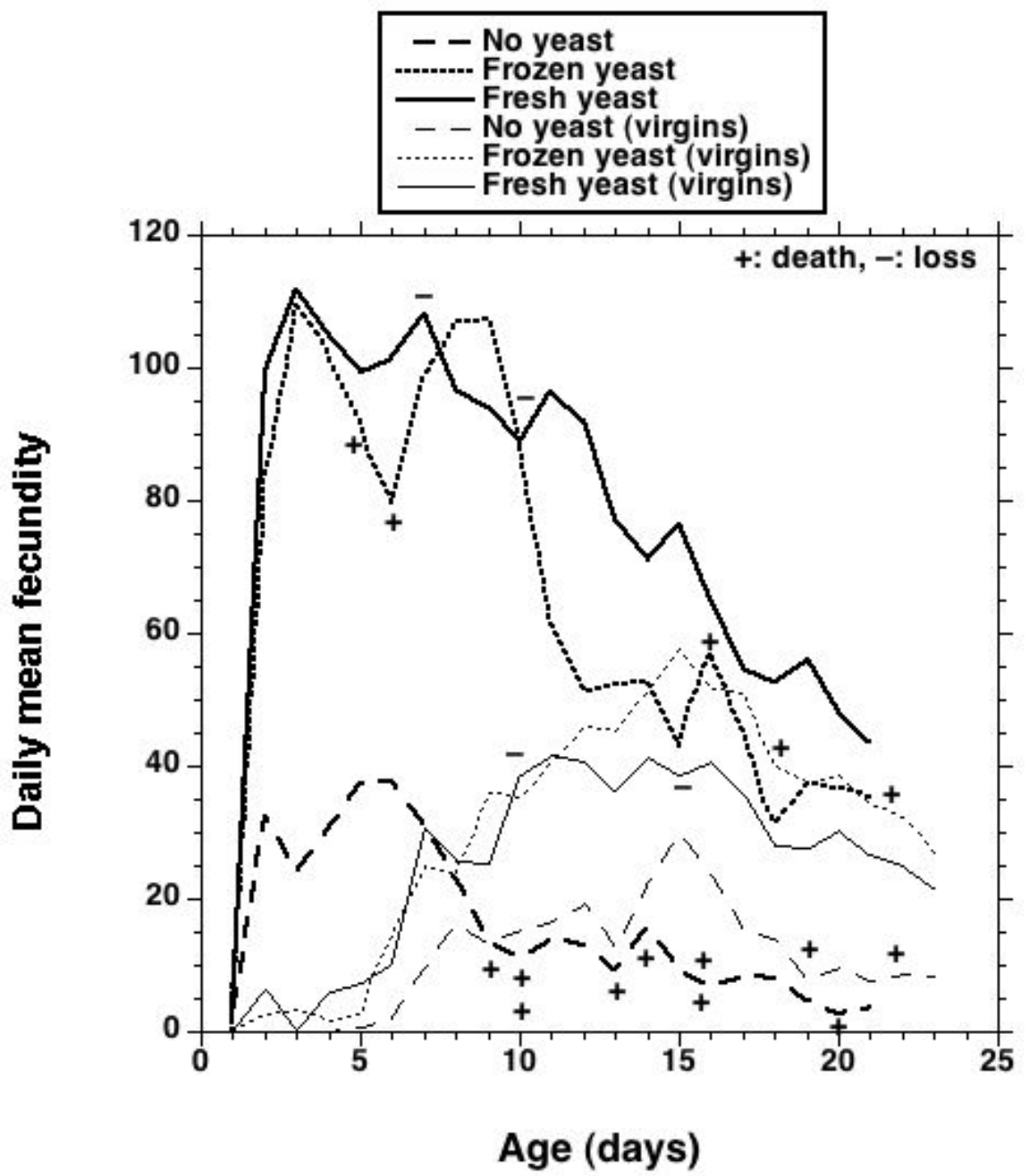

Figure 2. Daily mean fecundity (laid eggs in $24 \mathrm{~h}$ ) of virgin and mated females in fresh, frozen and no yeast groups. Crosses and minus signs indicate, respectively, death and escapes of females in each group. Eggs were recorded up to 21 days of age in mated females and up to 23 days in virgin ones. 


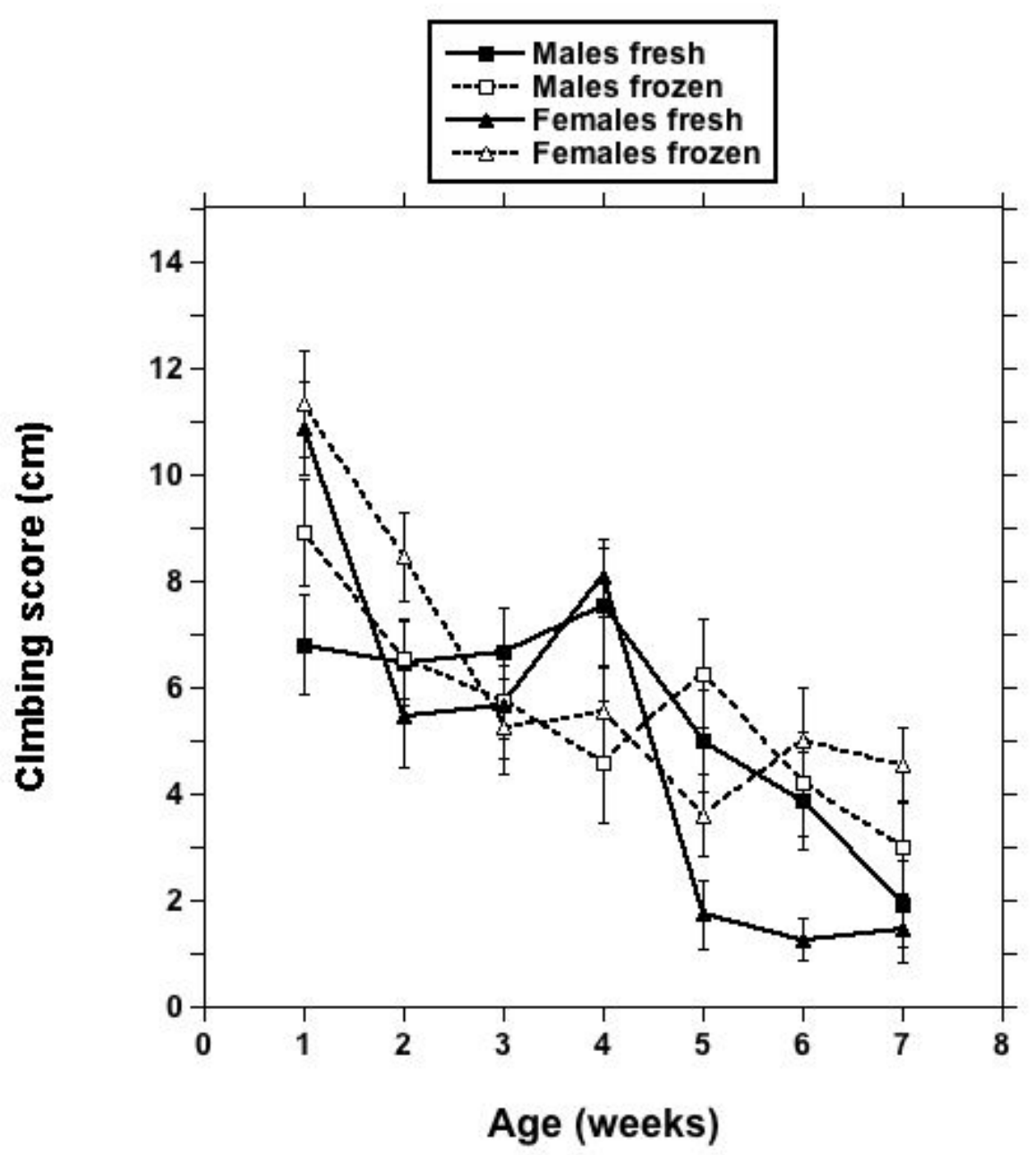

Figure 3. Mean climbing scores \pm SEM as a function of sex, age, and medium (fresh or frozen yeast). The climbing score is the height $(\mathrm{cm})$ reached by a fly in $20 \mathrm{~s}$ after the cessation of a mechanical stimulation. Each point is the mean of 15 flies. 


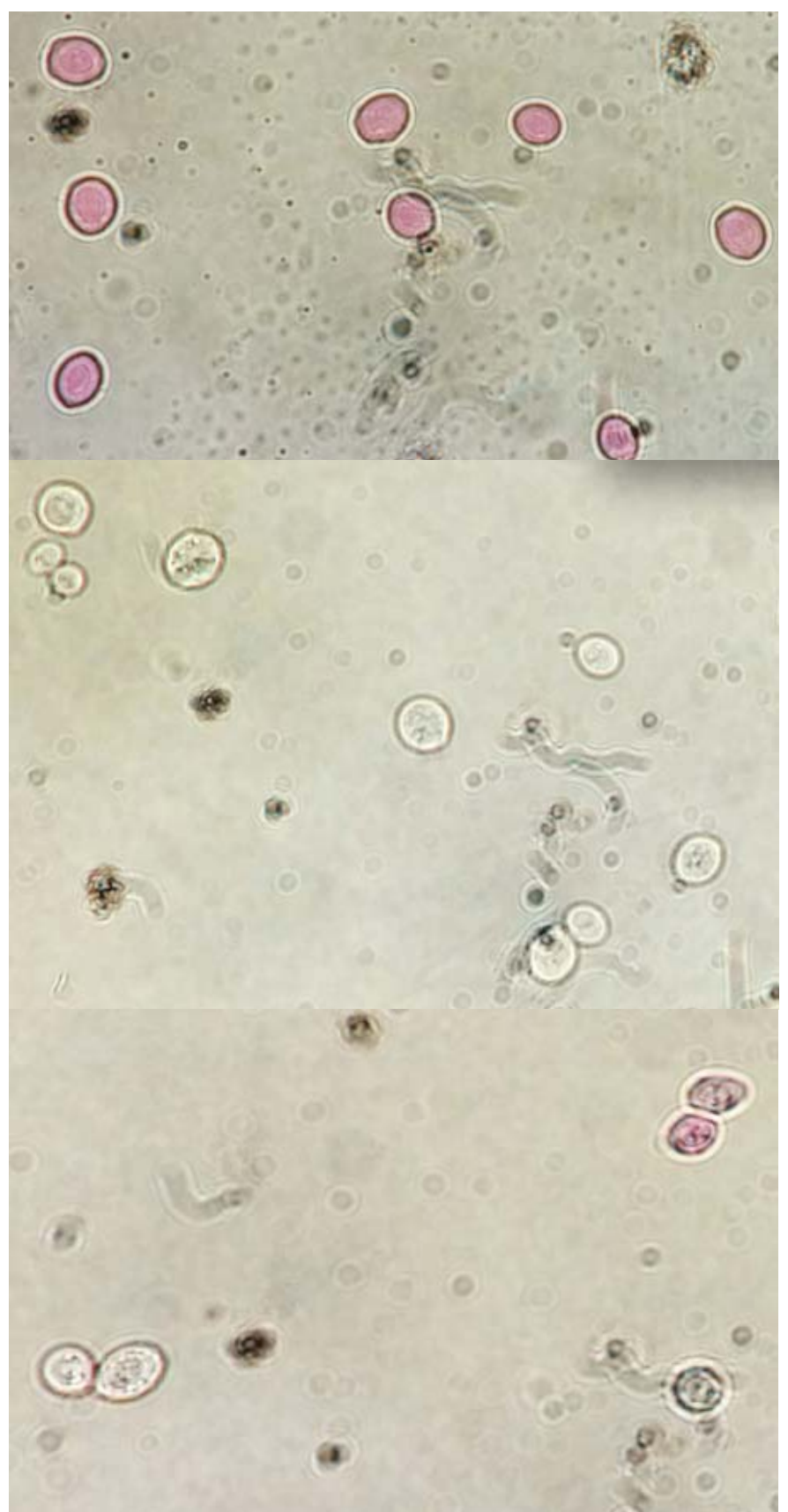

Figure 4. Pictures of yeast cells coloured by the dye phloxine $\mathrm{B}$ at a concentration of $0.25 \mathrm{mg} / \mathrm{mL}$. From top to bottom: Live yeast cells killed by heating: the cells are coloured; live yeast: the cells extrude the dye; live yeast kept for 9 months at ca $-12^{\circ} \mathrm{C}$ : ca $50 \%$ of cells are dead (picture taken one hour after adding dye). A count of dead and live cells showed that ca $50 \%$ of cells were dead $(62 / 118)$. 
- 29- 

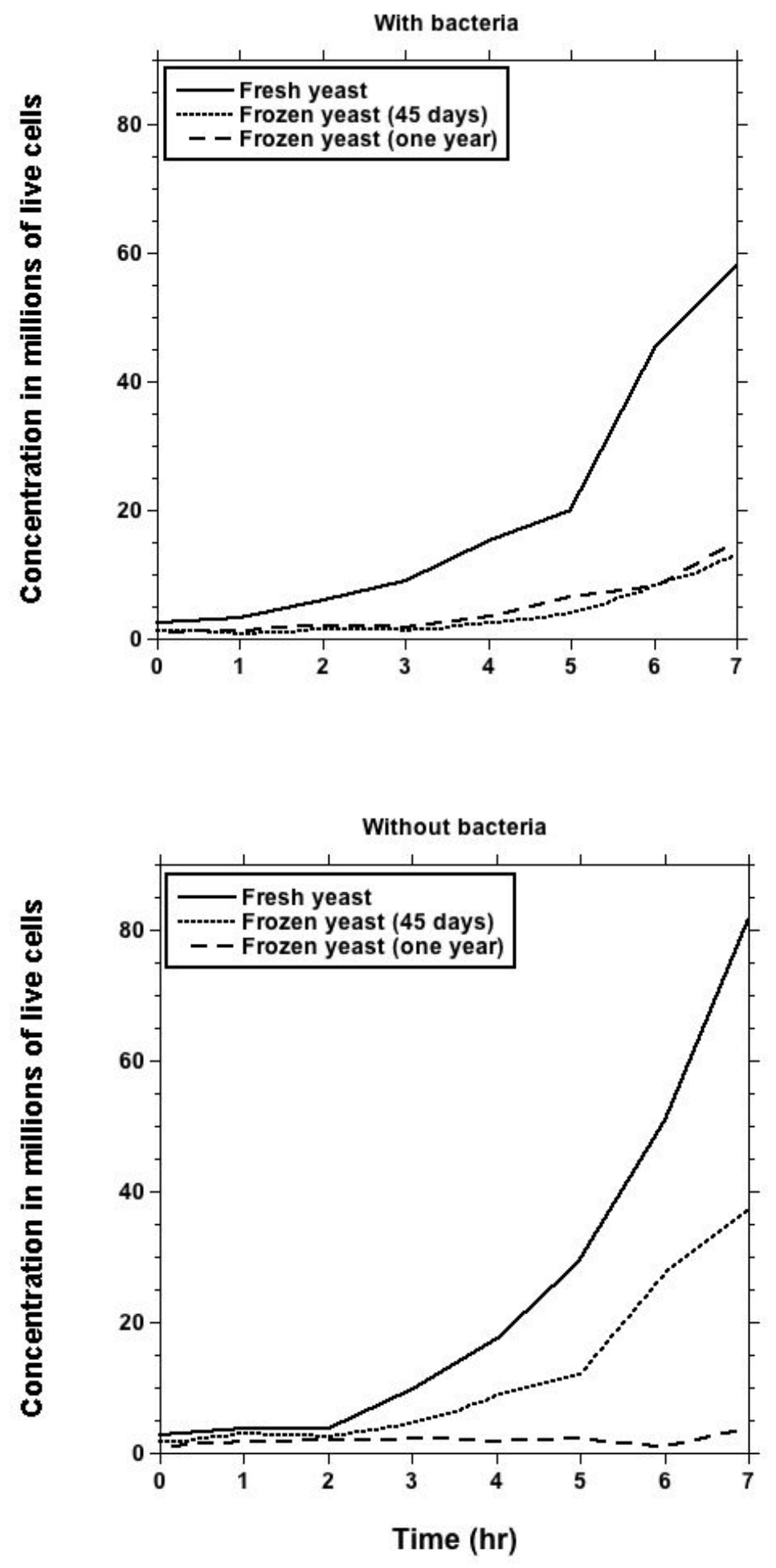

Figure 5. Cellular proliferation of yeast cells (see text for experimental details). Top: cells grown with bacteria in the flasks, bottom: cells grown without bacteria in the flasks. 

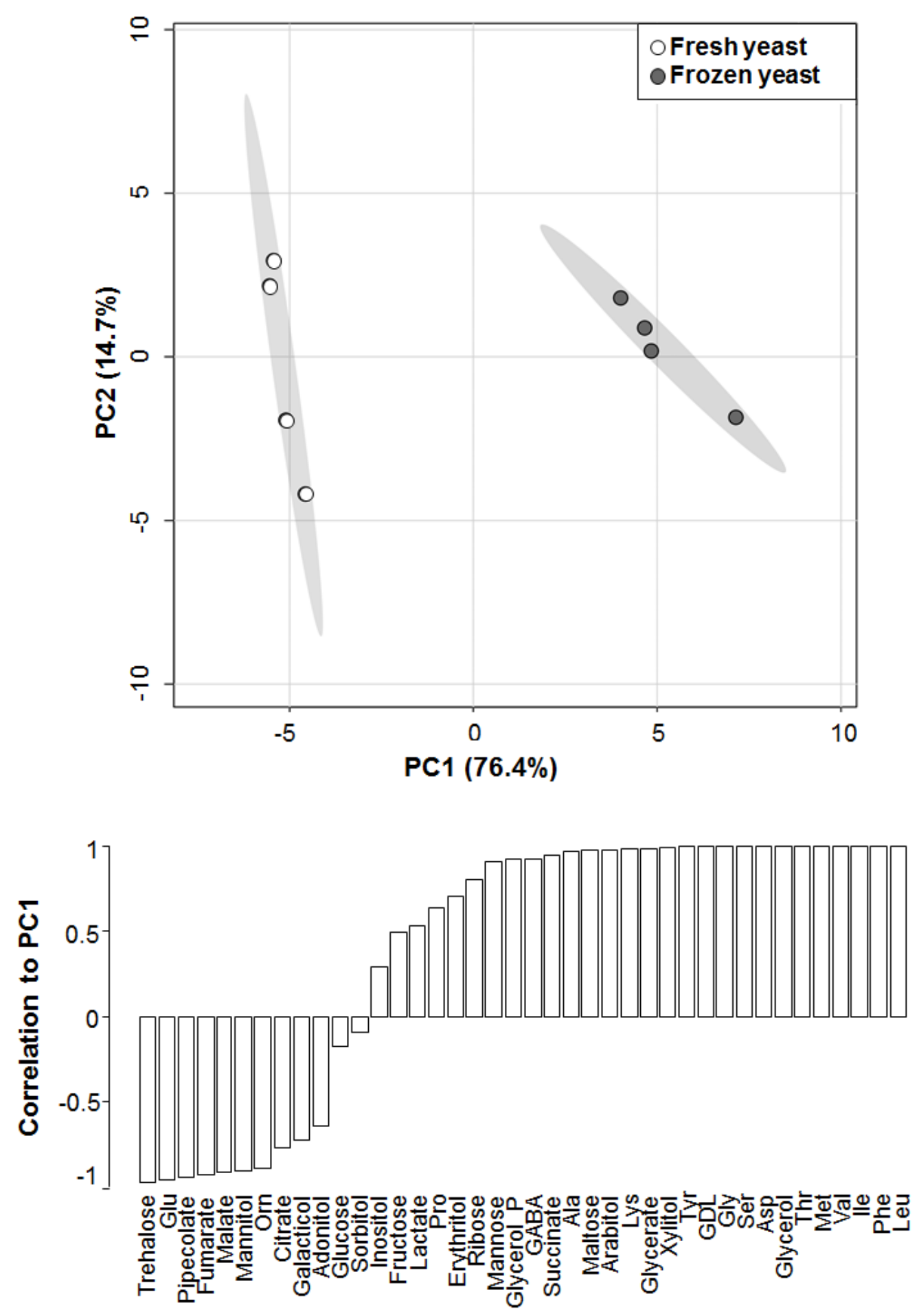

Figure 6. Multivariate analysis (PCA) on metabolomic data. Figure on top (4 replicates for each group) illustrates that plotting the first two principal components (PCs, proportion of explained variance by each axis in parentheses) results in a clear-cut separation of fresh versus frozen yeast metabotypes along PC1. Figure at the bottom illustrates the correlations of the different metabolite concentrations to PC1. 


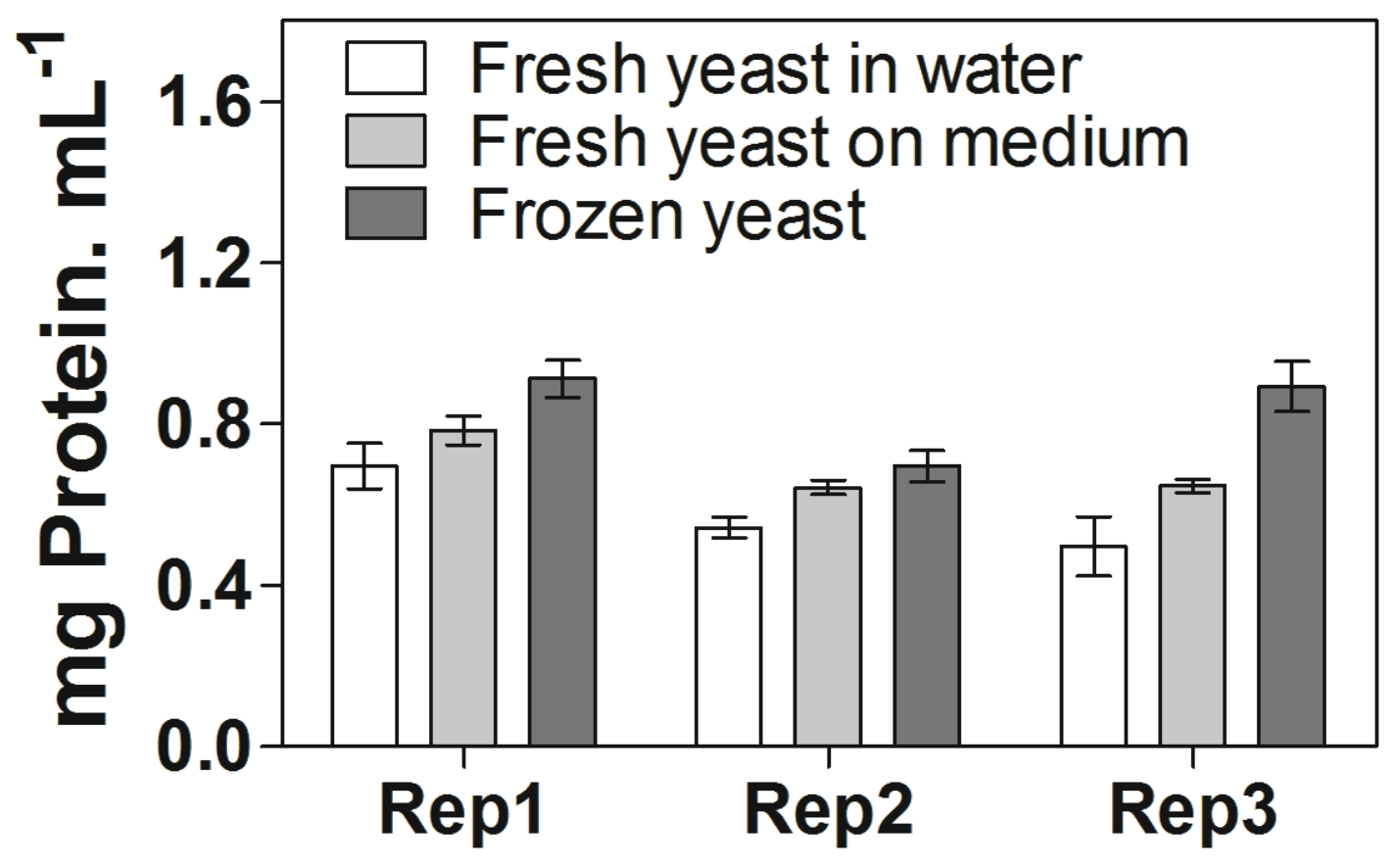

Figure 7. Total protein contents of extracts from 1) fresh live yeast diluted in water, 2) fresh live yeast placed at the surface of the medium, and 3) frozen yeast. The assay was replicated thrice (rep 1 to 3 ). 


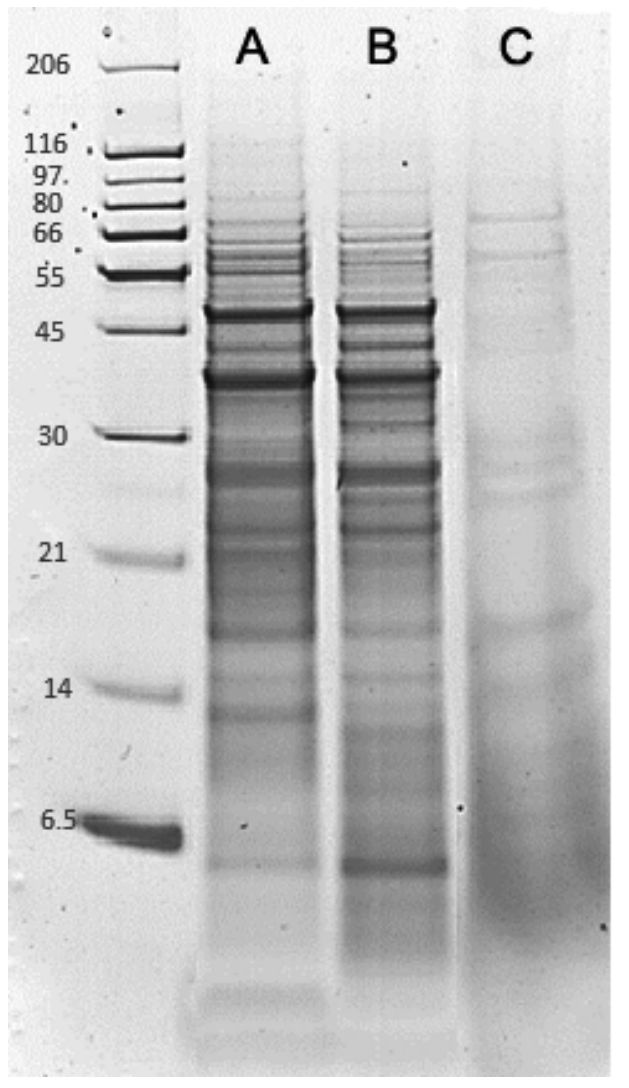

Figure 8: SDS-PAGE profile of protein extracts from fresh yeast (Lane A) and frozen yeast (lane B). Profile of trypsin-digested protein extract is shown in lane C. The gel was stained with EZBlue $^{\mathrm{TM}}$ Coomassie Brilliant Blue G-250. Molecular weight markers (in kDa) from unstained protein standards are indicated on the left part of the image. 